\title{
THE ROLE[S] OF THE BUSINESS ENGLISH TEACHER: A PRACTICAL APPROACH
}

\author{
Oana Alexandra ALEXA** \\ a) Alexandru Ioan Cuza University of Iași, Faculty of Economics and Business \\ Administration, Iaşi, Romania
}

Please cite this article as:

Alexa, O.A., 2021. The role(s) of the business English teacher: a practical approach. Review of Economic Studies and Research Virgil Madgearu, 14(2), pp.5-13. doi: 10.24193/RVM.2021.14.77.
Article History:

Received: 23 July 2021 Accepted: 13 October 2021

\begin{abstract}
Starting from Jeremy Harmer's (1994) general list and Evan Frendo's (2012) Business English-focused perspective on teacher roles, this paper aims to discuss in more detail the different dimensions of the teaching process I have identified during my seminars at the Faculty of Economics and Business Administration and provide practical examples of the teacher's role(s) in the classroom based on the fundamental process of needs analysis. It will show that teaching ESP is indeed more of a collaborative process between the students and the teacher and, consequently, the latter's role must shift according to the former's learning needs.
\end{abstract}

Key words: teacher roles; Business English; needs analysis; practice JEL Classification: A12; A22; I21; I23; M1; Z13

(C) 2021 Alma Mater Publishing House. All rights reserved.

* Corresponding author. E-mail address: oana.alexa@uaic.ro. 


\section{References:}

1. Brieger, N., 1997. The York Associates Teaching Business English Handbook. York: York Associates.

2. Ellis, M., Johnson, C., 1994. Teaching Business English. Oxford: Oxford University Press.

3. Frendo, E., 2012. How to Teach Business English. Essex, England: Pearson Education Limited.

4. Harmer, J., 2007. The Practice of English Language Teaching. $4^{\text {th }}$ ed. Essex, England: Pearson Education Limited.

5. Kumaravadivelu, B., 2003. Beyond Methods: Macrostrategies for Language Teaching. New Haven: Yale University Press. 